\title{
Implementation of the internal quality assurance system (SPMI) in junior high school
}

\author{
Sari Marlina ${ }^{1}$, Edi Harapan ${ }^{2}$, Nila Kesumawati ${ }^{2}$ \\ ${ }^{1}$ Sekolah Menengah Pertama Negeri 6 Talang Kelapa, Indonesia \\ ${ }^{2}$ Universitas PGRI Palembang, Indonesia
}

\begin{tabular}{l}
\hline Article Info \\
\hline Article history: \\
Received Jul $27^{\mathrm{h}}, 2021$ \\
Revised Aug $11^{\mathrm{h}}, 2021$ \\
Accepted Aug $30^{\text {th }}, 2021$ \\
\hline
\end{tabular}

\section{Keyword:}

Implementation

Internal Quality Assurance

System (SPMI)

SMP Negeri 1 Betung

\begin{abstract}
Improving the quality of education at SMPN 1 Betung is carried out through the implementation of an internal quality assurance system. The research objective was to describe the implementation of the internal quality assurance system at SMP Negeri 1 Model in Betung, Banyuasin Regency. The descriptive qualitative research method is the type of field study. The research subjects were the principal, deputy principal, administrative staff, operators, and teachers of SMPN 1 Betung. Data collection techniques were observation, interviews, and documentation. Data analysis techniques are in the form of collection, reduction, presentation, and conclusion. Data validity checks include credibility, transferability, dependability, and confirmability tests. The results showed that the implementation of the internal quality assurance system of SMP Negeri 1 Model in Betung, Banyuasin Regency was carried out in accordance with the instructions for the SPMI Dikdasmen Kemendikbud developed by the government through the model school program and pengimbasan. The implementation stage, namely preparation consisting of training, preparation, and socialization. SPMI implementation includes mapping, fulfillment of plans, implementation, monev, and setting new standards, mentoring, monitoring, monitoring and evaluation.
\end{abstract}

(C) 2021 The Authors. Published by IICET.

This is an open access article under the CC BY-NC-SA license

(https://creativecommons.org/licenses/by-nc-sa/4.0

\section{Corresponding Author:}

Marlina, S.,

Sekolah Menengah Pertama Negeri 6 Talang Kelapa, Indonesia

Email: sariyon24@gmail.com

\section{Introduction}

The quality assurance system for primary and secondary education is stipulated in the Regulation of the Minister of Education and Culture No. 28 of 2016 states that the quality of primary and secondary education is the level of conformity between primary and secondary education providers with national education standards. To improve the quality of education, it must be done continuously. Principals and educators are required to be responsible for the quality of the process and learning outcomes [1].

The Republic of Indonesia Government Regulation Number 32 of 2013 confirms that every education unit is required to implement an education quality assurance system under the supervision of LPMP. Quality assurance activities must be carried out so that education units throughout Indonesia can meet national education standards [2].

He education held in Indonesia still needs improvement. Based on the December 2019 Program for International Student Assessment (PISA) report, member of the National Education Standards Agency (BSNP) Doni Koesoema Albertus assessed that there are still differences in education services between public 
and private schools, between regions in Indonesia (Nuraini, 2020). Based on international institutional tests, Indonesia is still in 72 nd place out of 77 countries in terms of the quality of education [3].

Overcoming problems regarding the quality of education, the government's efforts to organize internal and external quality assurance systems ranging from tertiary institutions to primary and secondary education are under the auspices of the education quality assurance agency [5]. The implementation of SPMI through model schools is determined by LPMP to be the reference school by implementing quality assurance independently.

SMP Negeri 1 Betung by LPMP South Sumatra was chosen as a model school. Various problems were found in the implementation activities, among them the school community did not really understand the quality indicators of the SNP assessment as a reference for the quality of education, causing the school community to not understand. Unpreparedness of facilities and infrastructure in the field of information technology also causes a lack of information regarding school quality [4]. The participation and response of teachers and employees in implementation is still lacking. However, the implementation of SPMI at SMPN 1 Betung as a model school has been carried out based on the SPMI cycle even though it has not been maximized, it is still only fulfilling model school activities. Therefore, researchers conducted research at SMPN 1 Betung to determine how the implementation of the internal quality assurance system at SMP Negeri 1 Model in Betung, Banyuasin Regency. This study aims to describe the implementation of the internal quality assurance system (SPMI) program for SMPN 1 model in Betung, Banyuasin Regency.

The definition of quality in the context of education includes input, process, and output [6]. The broader concept of education quality has a meaning as a level of overall educational processes and outcomes that are determined according to certain approaches and criteria [7]. The output of education is school performance which can be measured from the quality, effectiveness, productivity, efficiency, innovation, and work morale. The educational outcome is how much the stakeholders receive or use the education graduates [8].

Quality education is the mandate of [21] concerning the National Education System, which states that the government determines national policies and national education standards that guarantee the quality of education stipulated through PP. 19 of 2005 which underwent amendments to [20] The quality assurance system for primary and secondary education must be implemented in accordance with the principles and stages stipulated in Permendikbud No. 28 of 2016. The smooth implementation of the quality assurance system in schools must be formed by a school education quality assurance team. The internal quality assurance system is a continuous cycle carried out by education units to ensure the improvement of the quality of continuous education so that it can build a quality culture in schools [9].

The implementation of an internal quality assurance system is developed by the government through model and monitoring schools. [10] SPMI implementation has several stages as follows. a) SPMI training b) SPMI implementation, which consists of quality mapping, compliance plans, quality compliance, monitoring and evaluation, and setting new standards and strategies c) Assistance d) Monitoring, e) Monitoring and evaluation.

\section{Method}

The method in this research is descriptive qualitative using a field study approach. Qualitative methods, namely research that leads to the understanding and interpretation of meaning based on the subject under study [11]. Descriptive research is research to systematically describe the facts, characteristics of a population or a particular field [12]. Field studies are collecting data directly into the field using observation, interview, and documentation data collection techniques [13]. The background in this research includes preliminary, prefield, field studies. data analysis, and compilation. The informants of this study are informants who are able to provide accurate information about the problem under study or often referred to as key persons, namely the principal, vice principal, administrative staff, operators, and teachers of SMP Negeri 1 Betung.

Sources of secondary data in this study are written data such as school data, teachers, employees and students, organizational structure, as well as administrative reports on the implementation of SPMI SMPN 1 Betung as a model school. Data collection procedures using observation, interviews, and documentation. [14] Data analysis techniques are analytical activities in research carried out by examining research instrument data, for example documents, notes, recordings, test results, and others. The data that has been obtained will be processed using qualitative research, then conduct a domain analysis to obtain a general and comprehensive description of the object of research through the process of data reduction, display and verification [15]. Checking data as suggested by [16] describes the purpose of testing the credibility of data to assess the validity of qualitative research findings. Transferability testing is external validity to show the accuracy of research 
results. The dependeability test is reliability. A reliable study is if other people can repeat the research process [17]. Confirmability test is a test of objectivity.

\section{Results and Discussions}

Based on a reference from the Ministry of Education and Culture (2017) which states that the implementation of an internal quality assurance system in schools is developed by the government through model school programs and monitoring. In implementing the SPMI, SMPN 1 Betung was appointed as a model school under the guidance of LPMP in South Sumatra Province. The stages of implementing the SPMI implementation at SMPN 1 Betung are based on the references set by the Ministry of Education and Culture, namely a) SPMI training. b) Implementation of SPMI which consists of quality mapping, fulfillment of improvement plans, implementation of quality improvement programs, monitoring and evaluation, and setting new standards and strategies c) Assistance d) Monitoring. e) Monitoring and evaluation.

The appointment of SMPN 1 Betung as the LPMP model school was proven by a decree from the head of the LPMP for the Province of South Sumatra. SMP Negeri 1 Betung deserves to be a model school that already has teaching resources, achievements both students and teachers, and adequate teaching and learning facilities.

There are eight keys for SPMI to run successfully, one of which is the socialization of SPMI to all school members.Administration related to SPMI training is well documented. This activity resulted in an activity proposal containing an attachment for the designation of a model school from LPMP, an assignment letter from the Banyuasin Regency Education and Culture Office, a model school assistance budget plan, a school accreditation certificate, an NPSN certificate, a follow-up plan, a TPMPS decree, the TPMPS organizational structure, the MOU. between LPMP and SMPN 1 Betung, and photo documentation of training activities.

The implementation of quality mapping at SMPN 1 Betung in 2019 has been carried out well, even though the implementation has not been maximized because it is constrained by school residents who do not really understand the various quality indicators of SNP assessment as a reference for education quality.

Quality mapping is still limited to meeting the requirements in the implementation of model school activities. The internal quality mapping is still in the form of data collection on education quality attainment only. This proves that at the time of filling in the EDS, they did not really understand and submit fully to the school operator as the data input. Completion of school self-evaluation assessments and assessment instruments have not been fully understood as school needs.

The factors that influence the implementation of the quality mapping of SPMI are not optimal, namely, the low awareness of the school community to participate in the implementation of the SPMI. The school community only thought that the implementation was the task of the team involved, so there was a lack of coordination. The school community also thought that the SPMI was only to complement the administration of a model school so that the school community's concern about the implementation of the SPMI was not responded to.

However, the quality mapping activity has been carried out by the TPMPS Team who is accompanied by the Bina supervisor. This activity was held for one day Thursday, 19 September 2019 at SMPN 1 Betung. Administration related to quality mapping in the form of invitation letters, attendance lists, SK mapping activities and quality compliance plans, assignments, minutes, hardcopy of material, quality mapping documents, quality report cards, and photo documentation of quality mapping activities. The output of this activity is expected to be able to make maps of educational attainment in educational units to analyze the problems faced and make recommendations for improvements.

The next implementation stage is to make plans for improving the quality of the school. [18] explains that the preparation of a quality improvement plan is carried out using a quality map as the main input. The output of this activity is in the form of a school development planning document and an action plan. Its implementation is combined with quality mapping so that administration related to quality planning is incorporated in quality mapping activities. The output of this activity is in the form of a fulfillment plan document that will be implemented. focused on content and assessment standards.

Planning activities have been carried out, but the use of the follow-up results of the mapping of education quality has not been used optimally for the need of continuous quality improvement. This is related to funding issues. 
Improving the quality of education must be carried out continuously. In this case, school principals and teachers are required to be responsible for the quality of the process and learning outcomes in order to improve the quality of education nationally (Rosyada, 2016: 1). Improving the quality of education is an effort that must be pursued continuously so that hopes for quality and relevant education can be achieved [19].

The next SPMI implementation activity is the implementation of the school quality assurance program. Quality compliance activities have been determined according to the instructions from the LPMP, namely content and assessment standards.

Activities in the form of IHT, RPP preparation and Hight Other Thinking Skill-based assessments. IHT will guide educators to apply the learning process, develop materials and approaches the HOTS-based learning process. Activity material regarding the learning process, educators will learn to apply interactive and integrative learning through a scientific approach to build knowledge, skills, and behavior.

Quality fulfillment activities in the form of IHT are carried out aimed at gaining insight for teachers in carrying out teaching and learning activities that lead to improving the quality of education at SMPN 1 Betung. The output of this activity is a document to fulfill the quality of education at SMPN 1 Betung, Banyuasin Regency. Output is the fulfillment of education quality and achievement of national education standards set in the education unit. This activity has resulted in an RPP format and an assessment that has been made by educators. This shows that after participating in IHT, educators have been able to prepare lesson plans and assessments based on higher order of thinking skills. There are additional knowledge gained by educators in order to improve the quality of education at SMPN 1 Betung.

Monitoring and evaluation activities to determine the suitability of the program implementation process with the prepared plan. The quality fulfillment strategy is only carried out if the previous quality fulfillment has been achieved (Apandi, 2019).

This monitoring and evaluation is carried out with the aim of knowing the completeness of administration and documentation related to the implementation of the SPMI at SMPN 1 Betung. The output of the activity resulted in an audit report on the implementation of quality compliance implementation of the SPMI which had been carried out at SMPN 1 Betung. If it is still not perfect, the internal audit provides recommendations in the form of suggestions that must be completed. This activity resulted in monev documents and an evaluation of the implementation of the SMI at SMPN 1 Betung.

The implementation of SPMI at SMPN 1 Betung ended with the establishment of new quality standards. However, this stage is only limited to planning, which has not been documented in the new strategy and quality determination document. The activity of determining the strategy and quality standard was limited to the internal planning of the principal with the TPMPS TEAM. The establishment of new standards and strategies is actually aimed at directing and encouraging schools to achieve the national education standards that have been established as a reference for the quality of education.

SPMI implementation at SMPN 1 Betung has been accompanied by local facilitators from the TPMPD TEAM of the Banyuasin District Education Office. Through filling in the instruments the facilitator monitors the progress of the SPMI implementation activities that have been carried out. The next stage of implementation is the scaling activity. Monitoring activities carried out to impact schools, namely Satria Nusantara SMPN, Monday 21 October 2019, Al Muhibbin Middle School, Tuesday 22 October 2019, PGRI Betung Junior High School, Tuesday, 2 October 2019, SMPN 3 Betung, Monday, 4 November 2019, SMPN 2 Betung Tuesday, November 5, 2019, and dissemination of the results of the scavenging, Thursday, November 7, 2019.

Documentation of application to impact schools, namely notification of application for application, schedule of application, attendance list, decree of activities, letter of assignment, minutes, and documentation of photos of activities. While dissemination, namely the invitation letter for the dissemination participants, attendance list, activity decree, assignment letter, minutes, hardcopy of material, and photo documentation of the activity.

Then, it was continued by participating in the pengimbasan dissemination activity at SMPN 1 Betung. The school invited the principal and representatives of the TPMPS team to participate in the dissemination activity. Arrangement of the schedule is coordinated internally from SMPN 1 Betung. According to the schedule, SMPN 1 Betung invited five impact schools in the Betung Subdistrict to carry out the dissemination activities for scrutiny

The purpose of implementing the pengimbasi is to determine the implementation of the SPMI that has been implemented by the impact school. The schools affected by SMPN 1 Betung are SMPN 2 Betung, SMPN 
3 Betung, SMP Satria Nusantara Betung, SMP PGRI Betung, and SMP Al Muhibbin Betung. Monitoring and Evaluation Regarding the impact, schools can benefit from knowledge to implement the SPMI implementation in their respective schools. Impact schools have produced a TPMPS team.

Documentation of application to impact schools, namely notification of application for application, schedule of application, attendance list, decree of activities, letter of assignment, minutes, and documentation of photos of activities. While the dissemination, namely the invitation letter for the dissemination participants, attendance list, activity decree, assignment letter, minutes, hardcopy of material, and photo documentation of the activity.

Then, it was continued by participating in the pengimbasan dissemination activity at SMPN 1 Betung. The school invited the principal and representatives of the TPMPS team to participate in the dissemination activity. Arrangement of the schedule is coordinated internally from SMPN 1 Betung. According to the schedule, SMPN 1 Betung invited five impact schools in the Betung Subdistrict to carry out the dissemination activities for scrutiny

The purpose of implementing the pengimbasi is to determine the implementation of the SPMI that has been implemented by the impact school. The schools affected by SMPN 1 Betung are SMPN 2 Betung, SMPN 3 Betung, SMP Satria Nusantara Betung, SMP PGRI Betung, and SMP Al Muhibbin Betung. Monitoring and Evaluation Through pengimbasan schools, the impact can get the benefits of knowledge to implement the implementation of SPMI in their respective schools. Impact schools have produced a TPMPS team.

The final stage of the entire series of activities implementing SPMI is monitoring and evaluation. This activity is carried out by the facilitator by involving school components consisting of the principal and the TPMPS team.

The purpose of monitoring activities is to report the results of activities by filling in the given instruments. The results of monitoring of the implementation of the implementation at SMPN 1 Betung were conveyed by the facilitator to LPMP to document the progress of school quality achievement in the SPMI Implementation system. The results of this activity are in the form of reports on the implementation of the SPM at SMPN 1 Betung.

Thus the discussion about the stages of implementation at SMPN 1 Betung. Through SPMI implementation activities, provide lessons to document the administration of each activity properly. This activity also provides lessons for time discipline because all activities must run on time. All activities that will be carried out for one semester are clearly scheduled. Although it is racing with teaching and learning activities that must also be carried out.

\section{Conclusions}

Based on the formulation of the problem, the results of the research description, and the discussion that has been carried out by researchers on the implementation of SPMI at SMP Negeri 1 Betung, the researchers concluded that the implementation of SPMI at SMP Negeri 1 Model in Betung has been carried out based on the instructions for implementing the SPMI Dikdasmen. Its implementation has referred to the National Education Standards. Steps for quality assurance have been carried out starting from quality mapping, compilation of compliance plans, quality implementation, quality evaluation, and standard setting. From the results of the implementation of SPMI, it has been able to improve the quality of education and build a quality culture in schools.

\section{References}

Rosyada, Dede. 2016. The role of the principal in improving the quality of education at http://dederosyada.lec.uinjkt.ac.id/reviews/perankepalasekolah in improving education quality (accessed May 14, 2020).

Aris, Muhammad. 2019. Implementation of the Internal Quality Assurance System (SPMI) Model School for Junior High School (SMP) A. Wahid Hasyim Tebuireng Jombang to the Imbas School [thesis]. Surabaya (ID): Sunan Ampel State University Surabaya.

Cahyo, Indro. 2019. A Strategy for Improving the Quality of Education in Indonesia https://yoursay.suara.com/lifestyle/2019/12/31/124101/sebuah-strategi-untuk-penlikasi-mutu-pend Pendidikan-di-indonesia?page=all ( access 22 December 2020)

Ministry of Education and Culture, Directorate of Primary and Secondary Education. 2017. Quality Indicators: In Primary and Secondary Education Quality Assurance. 
Ministry of Education and Culture, Directorate of Primary and Secondary Education. 2017. Guidelines for the Implementation of Education Quality Assurance by the Education Unit.

Mulyasa, E..2002. School Based Management: concept, strategy, and implementation. Bandung: PT Remaja

Fitrah, Muh. 2017. The role of the principal in improving the quality of education. Journal of Quality Assurance. 33

Hope, Edi. 2016. The Principal's Vision as a Driving Force for Education Quality. Journal of Management, Leadership, and Education Supervision (JMKSP PGRI Palembang University), 1 (2): 134

Mufakat, Sapta. 2019. The Strategic Role of TPMPS in the Quality Assurance of Education in Riau Islands Province. https://www.scribd.com/document/ 421668620 / Role-Strategic-TPMPS-In-

Ministry of Education and Culture, Directorate of Primary and Secondary Education. 2017. Development of School Models and Patterns of Advice.

Thesis Writing Team. 2020. Guidelines for Thesis Writing. PGRI Palembang University Postgraduate Program.

Muhyiddin et al ... 2017.Economic and Social Research Methodology. Jakarta: Four Salemba

Agung. 2011. Explanation of the Research Field Study. http://teoriilmupemerintah.blogspot.com/2011/06/penjelas-studi-lapangan-pen Research.html 23 December 2020

Khairil, Muhammad. 2020. Data Analysis Techniques - Definition, Types, and Stages at https://www.quipper.com/id/blog/tips-trick/school-life/teknik-anal-data-pengentuk-jenis-dantahapannya/ ( access January 5, 2020)

Miles and Huberman. 2013. T ranslational Qualitative Data Analysis by Tjetjeb Rohendi Rohandi. Jakarta: University of Indonesia.

Hariyanti, May. 2020. Testing the Credibility of Data on Qualitative Research at https://www.kompasiana.com/meykurniawan/556b6d46957e61fc617096a0/pengujian-kredibilitydata-pada-pen Research-kualitative? (access January 5, 2020).

Sugiyono. 2013. Educational research methods, quantitative, qualitative approaches, R\&D. Bandung: Alpha Beta.

Regulation of the Minister of Education and Culture No. 28 of 2016 concerning the Quality Assurance System for Primary and Secondary Education.

Fadhli, Muhammad. 2017. Management of Education Quality Improvement. Tadbir: Journal of Educational Management Studies STAIN Curup - Bengkulu | p-ISSN 2580-3581; e-ISSN 2580-5037. 1 (2): 216.

Republic of Indonesia Government Regulation No. 32 of 2013 concerning Amendments to Government Regulation No. 19 of 2005 concerning National Education Standards

Law No. 20 of 2003 concerning the National Education SystemMarzuki. 2002. Research Methodology. Jogjakarta: BPFE UII 